Contents list avaliable at Directory of Open Access Journals (DOAJ)
Aulad : Journal On Early Childhood
Vol 3 No 1 2020, Pages 20-28
ISSN : 2655-4798 (Printed); 2655-433X (Online)
Journal Homepage: https://aulad.org/index.php/aulad

\title{
Peran Keluarga dalam Konsep Psikologi Perkembangan Anak Usia Dini
}

\author{
Mutia Ulfa ${ }^{1}, \mathrm{Na}^{\prime} \mathrm{imah}^{2}$ \\ Pendidikan Islam Anak Usia Dini, UIN Sunan Kalijaga Yogyakarta \\ DOI: 10.31004/aulad.v3i1.46
}

\section{Article Info \\ Kata Kunci: peran keluarga teoripsikologi perkembangan}

Keyword: role of the family developmental psychology

\section{Abstrak}

Penelitian ini bertujuan menjelaskan tentang peran keluarga dalam perkembangan anak usia dini. Keluarga merupakan faktor utama dalam proses perkembangan dan pertumbuhan anak. Dengan demikian, tulisan ini mengulas mengenai peran keluarga dalam perkembangan anak melalui konsep psikologi perkembangan. Pendekatan yang digunakan adalah kualitatif yang melibatkan penelitian studi pustaka (studi literatur). Hasil dari penelitian ini menunjukkan bahwa secara teeoritik terdapat dua teori terdahulu dalam perkembangan dan pertumbuhan anak, diantaranya adalah teori Piaget dan teori Vygotsky. Menurut Piaget, anak usia dini merupakan pikiran yang pra-operasional. Dalam periode ini anak mampu mengembangkan tindakan yang baik dan terstruktur untuk menghadapi lingkungan, anak mulai memahami simbol yang digunakan dalam sebuah objek tertentu. Sedangkan menurut Vygotsky perkembangan anak pada masa awal yang menuju persiapan bersekolah didasari oleh jenis-jenis interaksi yang dimiliki anak di lingkungan sosial nya yang berpusat pada pencapaian tugas perkembangan. Terdapat banyak faktor yang menyebabkan pertumbuhan dan perkembangan anak. Secara umum, faktor tersebut dibagi menjadi 2 bahagian, yaitu faktor internal (dalam) dan faktor eksternal (luar/lingkungan).

\section{Abstract}

This paper aims to explain the role of the family in early childhood development. The family is a major factor in the process of development and growth of children. Thus, this paper reviews the role of family in child development through the concept of developmental psychology. The approach used is qualitative involving research studies of literature (literature studies). The results of this study indicate that theoritically there are two previous theories in the development and growth of children, including Piaget's theory and Vygotsky's theory. According to Piaget, early childhood is a pre-operational thought. In this period the child is able to develop good and structured actions to deal with the environment, the child begins to understand the symbols used in a particular object. Meanwhile, according to Vygotsky the development of children in the early period leading to school preparation is based on the types of interactions that children have in their social environment which are centered on achieving developmental tasks. There are many factors that cause a child's growth and development. In general, these factors are divided into 2 parts, namely internal (internal) and external (external / environmental) factors.

\footnotetext{
${ }^{1}$ Corresponding author at: Pendidikan Islam Anak Usia Dini, Universitas Islan Negeri Sunan Kalijaga Yogyakarta, Indonesia Email: mutiaulfa48@yahoo.co.id

${ }^{2}$ Pendidikan Islam Anak Usia Dini, Universitas Islan Negeri Sunan Kalijaga Yogyakarta, Email : drnaimah24@gmail.com
} 


\section{PENDAHULUAN}

Semua manusia memiliki siklus dalam kehidupannya, setiap siklus yang dimiliki terdapat proses perkembangan baik perkembangan dalam segi fisik maupun segi psikologinya. Tidak hanya orang tua, anak-anak juga memiliki proses pertumbuhan dan perembangan yang setiap anak berhak memiliki pertumbuhan dan perkembangan dalam aspek fisik dan psikologinya.

Pertumbuhan dan perkembangan seorang anak tidak lepas dari tanggung jawab orang tua maupun keluarga. Orang tua dan orang-orang yang terdekat dengan kehidupan anak, memberi pengaruh yang sangat besar terhadap pertumbuhan dan perkembangan anak (Irma, Nisa, \& Sururiyah, 2019). Keluarga merupakan lingkungan sosial terkecil yang secara tidak langsung dapat mempengaruhi proses perkembangan dan pertumbuhan seorang anak. Keluarga juga memiliki hubungan yang sangat erat dengan anak dibandingkan dengan masyarakat di lingkungan luas. Keluarga mampu memiliki cara tersendiri dalam membentuk kepribadian seorang anak, sebuah keluarga dikatakan berhasil dalam membantu proses pertumbuhan dan perkembangan anak yaitu dengan terbentuknya kepribadian yang matang dalam hidupnya sehingga anak menjadi seseorang yang bebas bereksperesi, berekreasi, berprestasi, dan juga mengaktulisasikan dirinya dalam lingkungan masyakarakat.

Perkembangan anak merupakan suatu proses perubahan perilaku yang belum matang menjadi matang, dari sederhana menjadi sempurna, suatu proses dari ketergantungan menjadi seseorang yang lebih mandiri. Sebagai orang tua maupun pendidik harus memiliki peran yang maksimal untuk mendukung proses pertumbuhan dan perkembangan anak.

Lingkungan keluarga merupakan pondasi awal dalam proses perkembangan dan pertumbuhan anak, oleh karena itu kedudukan keluarga merupakan kedudukan tertinggi dalam proses perkembangan anak adalah sangat penting. Dalam proses perkembangan anak usia dini tidak lepas pada perkembangan yang dicapai satu tahap, diharapkan menjadi lebih meningkat dari pada sebelumnya.

Pada era revolusi industri 4.0 banyak orang tua yang kurang peduli terhadap proses perkembangan dan pertumbuhan anak usia dini sehingga peran orang tua kepada anak untuk mendampingi segala aspek perkembangan dan pertumbuhannya kurang maksimal. Akhir-akhir ini banyak orang tua yang memprioritaskan pekerjaan dalam kehidupan nya sehingga setiap proses perkembangan dan pertumbuhan anak tidak terealisasikan dengan baik.

Dengan demikian, maka era revolusi industru 4.0 yang semua berbasis teknologi tidak menghalangi orang tua maupun keluarga dalam menjalankan perannya untuk membantu segala aspek perkembangan dan pertumbuhan anak. Orang tua yang ikut berpartisipasi dalam memberi dukungan penuh untuk anaknya maka perkembangan dan pertumbuhan anak akan berkembang semaksimal mungkin.

Untuk bisa menjadi orang tua dan keluarga yang bisa memberikan perhatian penuh dalam proses perkembangan dan pertumbuhan anak, maka orang tua harus memiliki pemahaman tentang bagaiamana pentingnya peran orang tua dalam proses pertumbuhan anak dalam konsep psikologi perkembangan. Dalam konsep psikologi perkembangan bahwa terdapat beberapa teori yang dapat dijadikan acuan dalam memberikan pengetahuan kepada orang tua dan keluarga bahwa perkembangan dan pertumbuhan anak akan maksimal apabila didukung oleh peran orang tua dan keluarga yang maksimal pula.

Terwujudnya perkembangan anak yang baik dikarenakan peran keluarga dalam pengasuhan anak yang dilakukan secara maksimal. Dengan demikian, keluarga sangat berpengaruh dan bertanggung jawab yang besar terhadap perkembangan anak agar berfungsi bagi dunia, akhirat, negara, sekolah, dan lain sebagainya sehingga anak mampu berkembang sesuai degan tahap perkembangannya.

\section{KAJIAN TEORITIK}

Dalam konsep psikologi perkembangan terdapat teori-terori yang menjelaskan tentang proses pertumbuhan dan perkembangan anak yaitu teori Piaget dan Vygotsky.

\section{Teori Piaget}

Menurut Piaget, anak usia dini merupakan pikiran yang pra-operasional. Dalam periode ini anak mampu mengembangkan tindakan yang baik dan terstruktur untuk menghadapi lingkungan, anak mulai memahami simbol yang digunakan dalam sebuah objek tertentu (Patilima 2015, 12). Dalam proses perkembangan anak menurut Piaget adalah proses secara genetik yang merupakan dasar dari mekanisme biologis dalam perekmbangan bentuk syaraf. Semakin bertambah umurnya seseorang maka semakin sempurnalah susunan syarafnya dan makin meningkat pula kemampuaannya. Ketika seseorang mulai berkembang menuju tahap kedewasaan, maka akan mengalami adaptasi biologis terhadap lingkungannya yang akan menimbulkan perubahan-perubahan secara kualitatif di dalam struktur kognitifnya. Piaget sendiri tidak melihat perkembangn kognitif secara kuantitiatif. Dengan demikian Piaget memberi kesimpulan bahwa setiap anak memiliki perkembangan yang berbeda sesuai dengan tingkatan usiaa dengan keukuatan mental dalam perkembangan secara kualitatif (Arifin 2016, 52).

Piaget yakin akan perkembangan kognitif anak terjadi dalam empat tahapan. Yaitu : a) usia 0-2 tahun (tahap sensorimotor); b) usia 2-7 tahun (tahap pra-operasional); c) usia 7-11 tahun (tahap operasional konkret) dan; d) usia 11-15 tahun (tahap operasional formal) (Mu'min 2013, 91). Jika terdapat keluarga yang memiliki anak 
yang berusia 0-2 tahun harus dalam perhatian yang ekslusif dalam setiap perkembangan anak pada usia tersebut. Menurut Piaget pada masa sensorimotor dan praoperasional anak sangat berpengaruh dalam usia 0-2 tahun. Sebagai orang tua harus memperhatikan beberapa hal mencakup perkembangannya baik dalam pengawasan maupun menjalakan perannya sebagai orang tua secara rinci dalam perkembangan kognitif seorang anak dalam tahap sensorimotor (Paul 2001, 102). Berdasarkan klarisifikasi tersebut, anak usia dini sedang berada pada tahap sensorimotor dan pra operasional. Pada tahap sensorimotorik, bayi mengalami kemajuan dalam mengambil tindakan. Sedangkan tahap pra operasional yang dimulai antara usia 2-7 tahun merupukan tahap kedua setelah tahap pertama dari Piaget. Dari tahap kedua, anak mulai memahami dunia dengan kaat-kata dan gambar. Mereka muali mengembangkan sebuah pemahaman yang stabil dan dapat melakukan penalaran (Pratiwi, Yarliani, and Ageng 2017, 57).

Dalam tahapan sensori motor yang diwawli sejak kelahiran hingga sekitar usia dua tahun. Pada tahapan ini seorang bayi muali mampu memahami dunia dengan mengkoordinasikan pengalaman penglihatan (sensory) mereka (seperti melihat dan mendengar) dengan gerakan motorik (otot) mereka (menggapai dan menyentuh), maka dari itu diartikan sebagai sensorimotor. Contoh dalam tahap sensorimotor menurut Piaget adalah bayi mulai mampu memahami lingkungan dengan menggunakan pengalaman penglihatannya dan tindakan fisik. Seorang bayi dapat dikatakan maju seangkah dari hari sebelumnya dan mengarah kepada tindakan pemikiran dan geraknya yang secara simbolik ke tahap akhir (Santrock 2010, 48). Sejak usia 0-2 tahun dalam tahapan perkembangan sensorimotor anak ditandai pada pertumbuhan kognitif yang mendasari pada perlakuan penglihatan dan gerakan. Tindakan pertama yang membentuk relasi secara refleks, mampu mengikuti tindakan orang yang telah berlalu, dan menyusun arti baru dalam pemecahan masalah dengan cara menggabungkan yang sebelumnya dengan pengatahuan. Dalam periode yang sangat singat 2 tahun, anak telah mengubah dirinya dari organisme yang sama sekali tergantung dengan sifat bawaan menjadi orang yang mampu berfikir secara simbolis (Suyadi 2010, 190). Dari penjelasan tahap sensorimotor tersebut, anak mulai mampu membentuk pengetahuannya sendiri, ia mampu mengasimilasi dan mengakomodasi sesuatu yang terjadi pada dirinya dalam lingkungannya untuk menunjukkan bahwa anak aktif mampu membentuk pengetahuan sejak lahir. Setiap stimulus yang diberikan oleh orangtuanya nanti akan menjadikan seorang anak untuk melakukan adaptasi yang sesuai dengan akomodasasi maupun asimilasi yang bekerja dengan cepat untuk mempengaruhi perubahan-perubahan pada anak secara berkelanjutan. Dengan demikian, setiap perilaku maupun tingkah laku anak menunjukkan perkembangan kognitif secara kualitatis. Dalam perkembangan ini terjadi secara terus menerus dan berkelanjutan karena periode yang sebelumnya menjadi titik berat dalam perkembangan periode selanjutnya.

\section{Teori Vygotsky}

Vygotsky memandang bahwa sebuah perkembangan anak diawali masa awal yang menuju persiapan bersekolah didasari oleh jenis strategi yang dimiliki anak di lingkungan sosial maupun sekolahnya yang didasari oleh tugas pencapain perekembangan anak. Pada Zona Perkembangan Dekat (ZPD) Vygotsky memahami bahwa terdapat kerumitan relasi yang mencerminkan hubungan antara pembelajaran dengan perkembangan yang dinamis berbentuk siklus mental seorang anak yang memiliki manfaat bersama dalam bentuk tersendiri. Zona Perkembangan Dekat yang digunakan oleh Vygotsky mendefenisikan bahwa Perkembangan anak biasanya diartikan sebagai sebuah skala yang merupakan titik-titik dari hubungan dalam keterampilan dan kemampuan dalam sebuah kesatuan yang memiliki tingkat penguasaan yang berbeda-beda. Seiring dengan perkembangan seorang anak Anak yang memiliki ZPD tidak tetap akan sering berubah-uabh dalam proses pembelajaran. Jika anak melakukan sesuatu pada hari ini, hanya sebagai bantuan dirinya untuk proses belajar hari berikutnya (Jaipul L. Roopnarine 2015, 248).

ZPD memiliki batasan diantaranya adalah baras bawah dan batas atas, dimana batas bawah dari ZPD yaitu tingkah permasalah yang mampu dipecahkan anak dengan sendirian, sedangkan dengan batas atas dari ZPD yaitu kemampuan tanggung jawab anak bertambah atau anak mampu menerima tugas tambahan dengan bantuan orang yang lebih mampu dari dirinya. Hal ini dapat dilaksanakan dengan cara scaffholding. Scaffholding adalah sebuah cara yang mampu mengubah level dalam dukungan tertentu. Menurut Vygotsky, setiap anak yang memiliki banyak konsep dalam perkembangannya tetapi belum sistematis,logis, dan rasional. Percakapan antara anak dengan orang khususnya orang tua akan lebih memahami dalam membantu anak menjadi seorang yang lebih sistematis, logis, dan rasional. Anak-anak harus dibiarkan secara bebas dan berkembang dengan bebsa untuk mengetahui sesuatu yang belum diketahuinya. Dengan demikian, semua akan memiliki manfaat dan fungsi dalam tumbuh kembang anak dalam lingkungan sosialnya dan pergaulan seorang anak dengan anak lainnya. Secara singkat schaffoloding memiliki beberapa macam diantaranya adalah: 
Tabel 1 Schaffolding

\begin{tabular}{|c|c|c|}
\hline No & Tipe Schaffolding & Contoh \\
\hline 1. & Model & $\begin{array}{l}\text { Setiap orang tua harus memberikan trik pada anak untuk memegang sendok dan } \\
\text { garpu yang baik dan benar untuk kegiatan makan, dan kemudian orang tua } \\
\text { meminta anak untuk mengikuti kegiatan yang telah dilakukan. }\end{array}$ \\
\hline 2. & Berpikir Kritis & $\begin{array}{l}\text { Pendidik dan orang tua memberikan demonstrasi kepada anak terhadap } \\
\text { pemikirannya terhadap strategi meggunakan pensil untuk membuat garis lurus. }\end{array}$ \\
\hline 3. & Pertanyaan & $\begin{array}{l}\text { Dari kedua tahap tersebut, orang tua maupun pendidik mengajak anak untuk } \\
\text { memecahkan masalah nya dan memberikan beberapa pertanyaan terhadap } \\
\text { asumsinya. }\end{array}$ \\
\hline 4. & $\begin{array}{l}\text { Menyesuaikan } \\
\text { Instruksional } \\
\text { dengan bahan }\end{array}$ & $\begin{array}{l}\text { Setiap orang tua mampu memberikan contoh-contoh yang benar seperti mmpu } \\
\text { menurunkan tingkat ketinggian ring permainan bola basket agar dalam } \\
\text { permainan bola basket anak mampu meningkatkan kemampuannya dengan } \\
\text { sempurna. }\end{array}$ \\
\hline 5. & Isyarat & $\begin{array}{l}\text { Setiap anak diberikan contoh yang dimudah ditiru dengan anak seperti saat sapi } \\
\text { belajar merangkak (Ulfa 2015, 127). }\end{array}$ \\
\hline
\end{tabular}

Menurut Vygotsky, alat yang sangat berpengaruh dalam psikologis adalah ucapan. Karena ucapan mampu mengembangkan pikiran secara bebas dan perhatian pada pemahaman secara spontan, sebuah hak yang melainkan dengan yang lainnya. Selanjutnya Vygotsky berkata bahwa kebolehan anak untuk terlibat dalam pecakapan secara batin terdapat tiga tahap diantara adalah sebagai berikut:

a. Kesatu, merupakan tujuan kepada objek yang tiak berlangsung dalam hubungan timbal balik anak dengan oarng lain.

b. Kedua, ketika anak memasuki usia antara tiga tahun atau lebih, ia lebih memfokuskan terhadap ucapan yang sama terhdapa diri sendiri.

c. Ketiga, saat usia delapan tahun katas, ujaran dalam hati anak sama sekali tidak dapat didengar

\section{METODE PENELITIAN}

Penelitian ini adalah penelitian studi pustaka atau studi teks. Dalam penelitian studi pustaka atau studi teks mencakup beberapa bagian. Pertama, telaah teori yang merupakan langkah disiplin ilmu yang perlu di lanjutkan secara empiris untuk memperoleh kebenaran secara empiris pula. Kedua, studi yang beruapaya dalam mempelajari seluruh obyek penelitian secara teoritik yang terkait dengan validitas. Ketiga, studi yang berupaya mempelajari teoritik linguistik. Keempat, adalah studi karya sastra. Adapun penelitian ini lebih kepada studi pustaka yang mengkaji peran keluarga dalam pertumbuhan dan perkembangan dalam teori psikologi perkembangan. Tentunya penelitian ini akan sedikit membantu bagi para orang tua maupun pendidik agar lebih memahami bahwa terdapat teori-teori yang membahas tentang pertumbuhan dan perkembangan anak usia dini dalam lingkup psikologi perkembangan. Berikut langkah-langkah penelitian dalam bentuk siklus:

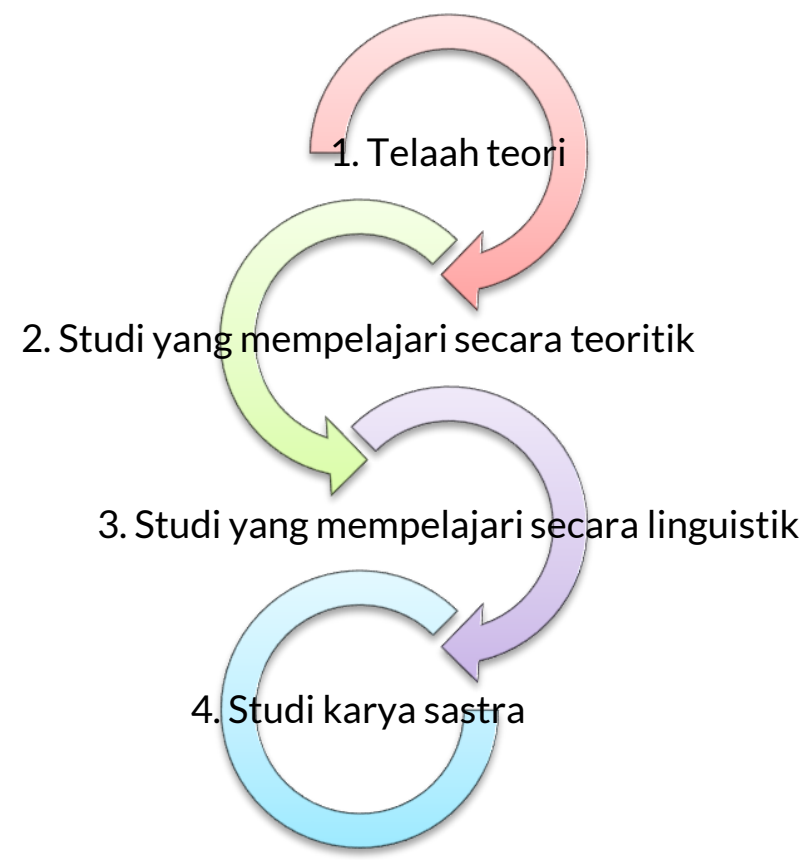

Gambar 1 Desain penelitian 


\section{HASIL DAN PEMBAHASAN}

\section{Analisis Teori Piaget}

Menurut teori Piaget setiap anak memiliki empat tahapan dalam perkembangan kognitifnya, mulai dari tahap sensorimotor, tahap pra-operasional, tahap operasional konkret, dan tahap operasional formal. Perkembangan dan pertumbuhan anak di dukung oleh adanya peran kedua orang tua dan keluarga yang harmonis. Dalam setiap perkembangan anak terjadi secara terus menerus sehingga anak menjadi seorang dewasa dengan proses perkembangan dan pertumbuhan yang maksimal. Dengan demikian, maka setiap anak yang tumbuh dan berkembang dengan maksimal tidak lepas dari peran orang tua dan keluarga yang cukup.

Seorang pendidik harus menyadari bahwa anak memiliki tingkat ketertarikan dan model belajar yang berbeda dan pada waktu yang berbeda pula. Misalnya, seorang anak perempuan berada ditahapan berpikir konkret, ia mulai berfikir secara logis, tetapi sebagaian dari pikirannya tidak terlepas dari objek-objek dan aktivitas-aktivitas yang konkret. Dengan demikian, pembelajaran semestinya memberi kesempatan besar untuk anak agar ia mampu menghadapi kegiatan secara nyata. Contoh, apabila seorang guru ingin mengajarkan tentang bilangan pecahan, tidak seharusnya guru menggambar diagram-diagram, memberikan ia material secara umum dalam pembelajaran.

Hal yang harus diakui oleh setiap guru adalah setiap anak tidak mudah dalam menemukan hal baru dalam pengalaman pendidikan yang paling mendasar. Dalam tahpan kognitif dapat membantu dalam perkembangan pengetahuan anak, tetapi anak memili tahapan yang berbeda saat ia berada ditempat yang tidak dalam lingkungan tempat tinggalnya. Dengan demikian, dibutuhkan fungsi guru secara maksimal agar anak mampu memahami dan mengamati lebih dekat tentang perkembangan anak.

\section{Analisis Teori Vygotsky}

Menurut teori Vygotsky bahwa anak yang masuk dalam proses perkembangan diawali dengan proses kesiapan dalam memasuki lingkungan sekolah. Setiap anak yang dalam proses perkembangan memiliki titik-titik yang berhubungan dalam keterampilan dan kemampuan sesuai dengan tingkat penguasaan yang berbeda. Dengan demikian setiap orang tua selalu membantu anak dalam proses kesiapan memasuki lingungan sekolah yang bertujuan untuk dapat menjadikan seorang anak yang memiliki pribadi yang mandiri.

Menurut Vygostky jika guru ingin mengetahui apa yang sudah siap dipelajari anak, kita tidak bisa melihat hanya pada apa yang bisa mereka lakukan saat bekerja sendirian, tetapi juga harus melihat jauh ke depan dan kemana ia akan berjalan saat diberikan sejumlah bantuan dari orang lain.

Kontribusi terbesar pemikiran Vygotsky dibidang pendidikan adalah pentingnya kesadaran dalam pembelajaran, dalam pembahasan ini Vygotsky tidak menggunakan istilah tertentu, namun penelitiannya tentang bantuan memori dan konsep-konsep ilmiah menunjukkan cara-cara anak menjadi sadar akan pemikiran dan gagasan mereka sendiri, yang kemudian mulai melatih sejumlah pengendalian atas dirinya.

Vygostky memberikan pandangan anak TK yaitu:

"Terdapat seorang anak yang berusia 6 tahun yang memiliki hewan peliharaan yaitu seekor kucing yang dibawa saat ia berjalan-jalan bersama orang tuanya dengan mengendarai mobil. Kemudian saat mereka beradaa di suatu lapangan terlintas seekor sapi. Anak tersebut menjunjuk sapi dan secara spontan mengatakan "kucing". Orang tuanya secara langsung memberikan informasi bahwa binatangkan tersebut bukanlah seekor kucing melainkan kucing, dan sapi sangat berbeda dengan kucing"

Dalam pembahasan diatas, bahwa setiap anak harus memulai sendiri terhadap pengetahuan, pemahaman dan pembelajaran mereka dan tidak terlepas dari peran orang tua maupun oang dewasa yang disekelilingnya yang berfungsi sebagai guru atau fasilitator dan moderator sangat berpengaruh bagi anak. Dalam pandangan diatas juga ditekankan bahwa perlu adanya keterlibatan orang dewasa, orang tua, dan keluarga yang melibatkan dalam proses pembelajaran seorang anak.

Perkembangan dan pertumbuhan anak dimulai dalam sejak kandungan, dan anak dikatakan hidup dimulai saat sel telur dibuahi oleh sel sperma. Dari satu sel yang dibuahi, kemudian membelah secara berulang kali yang menghasilkan ribuan, jutaan, bahkan milyaran sel. Dengan demukian, bentuk sel dan fungsi yang sama berkembang menjadi sel yang bersifat khusus seperti sel syaraf, sel otot, sel darah, sel tulang. Setiap sel tersebut akan membentuk jaringan, misalnya jaringan syaraf, jaringan otot, jaringan darah, jaringan epitel, dan juga jaringn tulang. Kemudian setiap sel yang membentuk jaringan aken membentuk organ baru, mislanya otak, jantung, mata, telinga, dan kaki. Organ tubuh memiliki proses perkembangan yang sangat pesat dimulai saat prenatal dalam perkembangan otak. Setiap sel syaraf otak mulai terbentuk saat usia kehamilan mulai tiga bulan pertama. Dengan demikian, bayi yang berusia kurang lebih 2-3 bulan yang mana ukuran kepala jauh lebih besar dari organ lainnya (Permono 2013, 36). Perkembangan awal anak dimulai sejak dalam kandungan sehingga anak lahir ke dunia pun masih memiliki perkembangan dan pertumbuhan baik dari segi fisik maupun psikologis.

Dalam perkembangan jiwa maupun kepribadian seorang anak harus dilalui dalam beberapa tahapan, dalam setiap tahapan memiliki hubungan yang sangat penting yang harus dilanjutnkan ketahap selanjutnya. Sedangkan dalam lingkungan keluarga, anak memiliki perkembangan yang masih pemula yang sangat mudah 
dibentuk dalam proses perkembangannya, oleh karena itu dalam pembentukan kepribadian anak keluargalah yang sangat menentukan dalam perkembangan anak selanjutnya. Apabila terdapat keluarga yang sangat berpartisipasi dalam mewarnai sekaligus menerapkan kehidupan jiwa anak nya dengan suasana yang memiliki kasih sayang, menyenangkan, da menggembirakan serta selalu diselimuti keharmonisan dalam rumah tangga.

Keharmonisan dalam rumah tangga akan menjadikan jiwa maupun kepribadian seorang anak yang pengertian, peduli, memiliki perasaan terhadap orang lain, santun, ramah kepada orang lain, dan peka terhadap lingkungan sosialnya. Begitu juga sebaliknya, apabila keluarga yang mewarnai kehidupan jiwa anaknya tidak dengan penuh warna, maka jiwa dan kepribadian seorang anak terasa hampa dari rasa kasih sayang, penuh dengan ketidakharmonisan dalam rumah tangga dan menimbulkan jiwa dan kepribadian yang kasar, tidak dapat bersosisalisasi dengan baik dilingkungannya, tidak memiliki sopan dan santun, dan tidak bersahabat (Sukaimi 2012, 111). Dalam lingkup sosial, setiap anak yang memiliki kepribadian baik tidak lepas dari dukungan keluarga dan orang tua yang harmonis sehingga menjadikan seorang anak yang berkepribadian baik terhadap sesama dan juga orang lain. Begitu pula dengan anak yang tidak memiliki kepribadian baik dikarenakan oleh orang tua dan keluarga yang tidak mewarnai dalam aspek perkembangan dan pertumbuhannya sehingga menjadikan anak yang tidak dapat bersosialisasi baik dengan lingkungannya.

Keluarga merupakan suatu lembaga pendidikan dirumah yang menjadi "sekolah" pertama bagi anak agar sekolah tersebut memiliki tujuan untuk masa yang akan datang. Menurut F.J. Brown dalam artikel Khoiriyah Ulfa menjelaskan bahwa dilihat dari prospek sosiologi, keluarga dapat didefinisikan menjadi dua macam, yaitu a) dalam arti secara umum, keluarga merupakan seluruh keluarga yang memiliki hubungan darah maupun keturunan yang dapat disamaratakan dengan marga; b) dalam arti khusus keluarga merupakan sesuatu yang tidak pernah lepas dengan orang tua dan anak (Ulfa 2015, 125). Peran keluarga sangat mendukung dalam proses perkembangan dan pertumbuhan anak, apabila keluarga selalu membantu anak dalam proses perkembangan dan pertumbuhannya maka anak terebut akan menjadi pribadi yang mandiri. Dengan demikian, anak tumbuh dan berkembang sesuai dengan apa yang diperoleh dari keluarga maupun orang tua nya sendiri.

Jika terdapat anak yang mengalami korban dalam kerusakan keluarga maka perkembangan dalam tahapan selanjutnya akan susah dididik karena jiwanya yang tidak kuat (Suyadi 2015,151$)$ Apabila dalam menjaga keluarga dari hal-hal yang buruk, maka tidaklah mudah untuk diubah secara langsung untuk menjadi keluarga yang baik seperti yang diharapkan, namun dibutuhkan proses dalam memahami tugas yang harus dilaksanakan secara mendalam. Menjadi orang tua bukan hanya memberikan kewajiban dalam memenuhi kebutuhan hidup, melainkan harus memiliki kebutuhan hidup dalam bentuk rohaniah juga tidak kalah penting dari yang lainnya. Dengan cara membiasakan anak untuk mengenal hal-hal yang positif maupun pengenalan nilai kesusilaan dan agama, maka dengan cara tidak langsung anak akan terbentuk karakter yang berkahlak muliah ke masa selanjutnya. Sehingga pada waktunya anak sudah mengenal hal yang baik maupun buruk saat ia berada dalam proses interaksi sosial dalam kehidupan sehari-harinya.

Dari penjelasan diatas, terlihat bahwa peran keluarga sangat menentukan dalam perkembang pribadi seorang anak. Namun, dari seluruh keluarga yang ada di dunia tidak sedikit dari orang tua yang tidak memahami dalam perkembangan keseimbangan antara kebutuhan jasmani dan rohoani dalam aspek sritual anak. Kebanyakan orang tua lebih cenderung mensupport dalam kebutuhan jasmani dalam kecerdasan spritualnya sedangkan dalam kebutuhan rohani masih banyak orang tua yang tidak memprioritaskan dalam perkembangannya. Oleh karena itu, ada baiknya apabila anak dari dari mulai dalam kandungan ibu agar bisa menambahkan amal ibadahnya kepada Allah misalnya melakukan shalat wajib, maupun sunnah, berdzikir, berdoa, membaca Al-Qur'an maupun amal shaleh yang lainnya sehingga mampu dirasakan dalam perkembangan kepribadian anak sejak dalam kandungan.

Terdapat beberapa faktor yang menyebabkan pertumbuhan dan perkembangan anak. Secara global, faktor tersebut dibagi menjadi 2 bahagian, yaitu faktor internal (dalam) dan faktor eksternal (luar/lingkungan). Pertumbuhan dan perkembangan akan berjalan dengan baik apabila terdapat kerjasama antara faktor internal dan eksternal yang maksimal. Faktor internal terdiri perbedaan ras, suku, dan bangsa. Selain faktor interal juga terdapat faktor eksternal yang mempengaruhi pertumbuhan dan perkembangan anak, seperti gizi, psikologis, dan sosial ekonomi (Chamidah, 2009, 8).

Setiap pertumbuhan dan perembangan anak tidak lepas dari kerja sama. Seperti prinsip-prinsip perkembangan yaitu bahwa seluruh aspek perkembangan saling bekerja sama antara satu sama lain yang memiliki tujuan ke arah yang positif, seperti motorik kasar dan motorik halus, kemampuan motorik halus mulai berkembang dan berfungsi dari sejak lahir dan berkembang secara bersamaan dalam tingkatan variasi sesuai dengan pengalaman kasus yang terdapat di lingkungan yang mempengaruhi kondisi fisik maupun lingkungan (Solihin, Anwar, and Sukandar 2013, 70). Orang tua yang memiliki visi dan misi searah dalam proses perkembangan dan pertumbuhan akan menjadikan anak tumbuh dan berkembang kearah positif. Dengan demikian, orang tua harus memiliki tujuan kearah positif untuk menjadikan anaknya tumbuh dan kembang secara maksimal. Peran orang tua dalam hal ini tidak hanya memberikan dan mencukupi anak secara materi, namun orang tua juga harus ikut terlibat secara aktif untuk pertumbuhan dan perkembangan anak (Adhani, 2019).

Terdapat bukti yang menyatakan bahwa "perkembangan awal sangat penting" pada anak usia dini, diantaranya terdadapat 4 bukti yaitu: Pertama, sejalan dengan bertambahnya usia anak hasil belajar dan pengalamannya semakin memberikan peran yang dominan. Atas dasar ini, anak dapat diarahkan ke arah 
penyesuaian sosial yang lebih baik. Hal ini lebih tepat dilakukan terutama oleh keluarga, kemudian kelompok sosial yang lebih besar memberi warna dengan budaya dimana anak dapat melatih kemampuannya, jika anak dibiasakan pada hal yang baik, ia akan menyadari bahwa kebiasaannya tersebut merupakan hal yang paling baik. Kesadaran itu akan dibawa hingga ia dewasa dan kecil kemungkinan anak tersebut dapat pindah pada sosial yang salah. Kedua, perkembangan awal akan mudah berkembang menjadi kebiasaan, dimana hal ini akan mempengaruhi seseorang sepanjang hidup dalam penyesuaian perilaku dan sikap sosial anak. Ketiga, pengalaman pada masa kanak-kanak cenderung dipertahankan tanpa membedakan apakah pengalaman itu baik atau buruk, Keempat, seringkali muncul keinginan untuk mengubah pengalaman melalui berbagai materi edukasi. Dalam hal ini, perubahan harus semakin cepat disampaikan kepada anak karena dapat memacu anak untuk lebih mau bekerja sama dengan orang lain dalam menghadapi perubahan (Suyadi 2010, 70-71).

Berdasarkan empat bukti tersebut, dapat diambil kesimpulan bahwa setiap perkembangan pada masa usia dini menjadi acuan dalam proses perkembangan yang akan datang menuju masa selanjutnya. Sehingga setiap proses perkembangan anak terealisasikan secara maksimal dengan fungsi dan tujuan paud yang telah ada.

Menurut Piaget dan Vygotsky teori kosntruktivistik difokuskan pada siswa yang pembelajaran dan penilian nya menggunakan autentik. Menurut Gardner dan Miller materi autentik dijadikan sebagai rujukan dalam pembelajaran autentik, dan materi autentik bisa didapat oleh semua orang dalam bentuk intrekasi (Nurkholida 2018, 63). Terdapat sebuah rujukan dalam proses pembelajaran untuk anak menurut Gardner dan Miller yaitu pembelajaran autentik dimana materi pembelajaran autentik dapat diperoleh oleh semua orang khususnya dalam bentuk interaksi dengan orang lain. Dalam teori Piaget dan Vygotsky pembelajaran yang mendukung untuk anak adalah pembelajaran autentik.

\section{Peran keluarga dalam psikologi perkembangan anak}

Menurutt Iskardah dalam Mukti Amini, fungsi ibu bapak dalam proses perkembangan anak adalah sebagai berikut: a) memelihara kesahatan raga dan batin anak, b) menanamkan pondasi kepribadian yang baik, c) mengayomi dan memberikan dorongan anak untuk mengembangkan diri, d) memberikan fasilitas yang maksiaml dalam pengembangan diri anak, e) menciptakan suasa aman dan nyaman yang mendukung bagi perkembangan anak (Amini 2015, 10). Berdasarkan pendapat diatas, terlihat bahwa peran orang harus dijalankan dengan sesuai secara maksimal, tidak hanya dalam pendidikan, tetapi juga dalam pertumbuhan dan perkembangan anak

Keluarga adalah organisasi terkecil dalam masyarakat dan negara yang luas, yang terdiri dari bagian pada umumnya terdiri dari ayah, ibu, saudara kandung, kakek, nenek, sepupu, dan lain sebagainya. Lingkungan yang paling kecil juga disebut dengan keluarga yang bersifat primer, disitulah anak di besarkan dan diberikan pembelajaran awal untuk proses perkembangan dan pertumbuhan diri menuju ke tahap selanjutnya. Saat anak berada dalam lingkungan keluarga, ia mulai mendapatkan kasih sayang, pola asuh, perlindungan pertama yang dijadikan sebagai peran atau tanggung jawab orang tua dalam pertumbuhan dan perkembangan anak (Sukaimi 2012, 111). Peran keluarga sangat berpartisipasi dalam perkembangan fisik maupun mental seorang anak. Yang terpenting peran seorang ibu, karena ibu adalah pendidik utama bagi anak-anaknya yang dilahirkan hingga dewasa kelak. Dalam proses pertumbuhan dan perkembangan anak dibutuhkan pola asuh seorang ibu yang diberikan kepada anaknya untuk menyertakan nilai-nilai yang positif. Dalam konteks peran keluarga bertujuan untuk memandu dan membentuk anak agar menjadi manusia yang baik dimata Tuhannya (Permono 2013, 35). Dengan demikian, proses pertumbuhan dan perkembangan anak di dukung oleh pola asuh ibu yang menyertakan nilai-nilai positif kepada anak sehingga anak menjadi seorang makhluk yang berguna di mata Tuhannya.

Dengan itu, tampak bahwa tanggung jawab orang tua sangat berpengaruh dalam setiap perkembangan anak. Untuk seorang anak, keluarga adalah kelompok kecil dalam kehidupan keluarga yang manjadi wadah untuk menjadikan pribadinya yang lebih maju kea rah yang positif. Secara universal bahwa keluarga adalah temppat proses belajar anak dalam mengembangkan dan membentuk seluruuh fungsi sosialnya. Selain itu, keluarga juga adalah wadah untuk seorang anak untuk belajar dalam seluruh sikap untuk berbakti kepada orang tua dan Tuhannya. Dalam keluarga lah, anak di didik dalam proses pertumbuhan dan perkembangannya. Orang tua maupun keluarga harus mengerti dan meyakini bahwa anak hadir dalam ruang lingkup keluarga hanya sesaat dan akan tumbuuh dan berkembang hingga ia dewasa dan mampu membebaskan dirinya dari bingkai keluarga (Hasbullah 2012, 39). Keluarga merupakan lingkungan sosial terkecil yang memiliki pengaruh besar dalam pertumbuhan dan perkembangan anak, orang tua yang mendukung segala pertumbuhan dan perkembangan anak akan menjadikan dirinya lebih maju kea rah yang positif dengan segala fungsi sosialnya akan menjadi orang yang bermanfaat dan berguna.

Pertumbuhan dan perkembangan anak sangat dipenagruhi oleh bagian keluarga bersama ayah, ibu, dan anggota keluarga lainnya. Menurut beberapa ahli pendidik, anak sangat dekat dalam pertumbuhan dan perkembangannya dilingkungan, baik lingkungan jasmani maupun lingkungan adat. Setiap orang yang berada dalam lingkungan anak sangat berperan dalam psikologi perkembangan anak. Apabila anak dilahirkan dalam lingkungan yang baik, maka ketika ia besar nanti mempunyai pengaruh besar dalam perkembangan menuju masa selanjutnya, begitu pula sebaliknya. 
Dalam perkembangan dan pertumbuhan anak tidak lepas dari peranan keluarga secara maksimal, maka peran keluarga merupakan sesuatu kelakuaan secara interpersonal, perilaku, maupun kegiatan individu dengan individu lainnya dalam keadaan dan tempat yang khusus. Pengaruh perkembangan dan pertumbuhan seorang individu didasari oleh harapan dan pola perilaku dari keluarga, kelompok, dan masyarakat yang bersifat positif (Ulfa 2015, 137). Dalam kehidupan seorang anak yang menjadi guru pertama adalah orang tua yang kedudukan tertinggi dalam usaha menjaga dan membina perkembangan dari tahap ke tahap. Kewajiban orang tua dalam menumbuh kembangakan anak didasari oleh pemahaman dan landasan pendidikan iman dan ajaran Islam sejak proses perkembangnnya. Namun, hendaknya setiap orang tua memiliki trik tersendiri dalam perannya yang menerapkan pola asuh dan pola perkembangannya secara cepat dan maksimal. Dalam konsep perkembangan anak, tugas orang tua tidak hanyaa melahirkan anak, melainkan juga meberikan perhatian khusus, pola asuh yang maksimal, dan tak kalah penting dengan kasih sayang. Secara kompleks dapat dijelaskan bahwa peran orang tua dalam perkembangan anak yaitu; "orang tua adalah pengaruh besar dalam perkembangan dan pertumbuhan seorang anak dan juga sebagai pelindung utama dalam berbagai fase-fase perkembangan anak (Makhmudah 2018, 273). Oleh karena itu, orang tua adalah guru pertama yang membantu proses perkembangan dan pertumbuhan anak dari tehap ke tahap selanjutnya untuk memberikan perhatian khusus, pola asuh yang maksimal dan juga kasih sayang dari orang tua dan keluarga nya. Setiap keluarga memiliki trik dan cara tersendiri untuk membantu proses perkembangan dan pertumbuhan anaknya.

Semua orang tua mendambakan anaknya tumbuh dan berkembangan dengan normal seperti anak lainnya. Maka dari itu, peran dan tanggung jawab orang tua tidak lepas begitu saja, butuh strategi tersendiri yang maksimal agar peran orang tua berjalan dengan baik. Keluarga harus mampu membuat organisasi kecilnya memiliki fungsi dan tujuan yang bagus agar anak yang lahir memiliki fase-fase pertumbuhan dan perkembangan secara baik. Dari setiap anak mempunyai tahap dan perkembangan yang berlainan sesuai dengan cara yang dilakukan oleh orang tua nya, maka orang tua harus mengetahui bahwa usia anak dari 0-7 tahun perlakukan sebagai raja, usia anak dari 7-14 tahun perlakukan anak sebagai tahanan, dan usia 14-21 tahun perlakukan anak sebagai duta besar. Maka apabila setiap tahapan tersebut dilakukan secara baik dan benar, maka setiap tahapan perkembangan dan pertumbuhan anak akan menjadikan ia sosok seseorang yang mandiri, tanggung jawab, berkompeten, dan lain sebagainya.

\section{SIMPULAN}

Pertumbuhan seorang anak sangat berpengaruh dengan keluarga. Jika setiap pertumbuhan dan perkembangan anak berjelan dengan lancar maka adanya peran orang tua yang mampu mendukung secara penuh dalam setiap prsoses perkembangan anak. Dalam konsep psikologi perkembangan terdapat teori-teori yang menjelaskan tentang proses pertumbuhan dan perkembangan anak yaitu teori Piaget dan Vygotsky. Menurut teori Piaget, anak memiliki pemikiran secara pra-operasional. Pada periode ini anak mampu mengembangkan tindakan yang baik dan terstruktur untuk menghadapi lingkungan, anak mulai memahami simbol yang digunakan dalam sebuah objek tertentu. Sedangkan menurut teori Vygostky perkembangan anak pada masa awal yang mengarah ke persiapan sekolah yang didasari oleh tipe hubungan yang dimiliki anak di daerah sosial nya yang berkdudukan pada perolehan tugas perkembangan, berdasarkan pendapat Vygotsky mengenai Zona Perkembangan Dekat yang memberikan contoh kerumitan relasi antara perkembangan dan pembelajaran yang berenergi dalam bentuk pergantian dari cara belajar yang intelektual bersama dengan cara masing-masing.

\section{DAFTAR PUSTAKA}

Adhani, D. N. (2019). Peran Orang Tua terhadap anak usia dini (usia 2 tahun) yang mengalami Picky Eater. Aulad : Journal on Early Childhood, 2(1), 38-43. https://doi.org/10.31004/aulad.v2i1.18.

Amini, Mukti. 2015. "Profil Keterlibatan Orang Tua dalam Pendidikan Anak Usia TK." Jurnal IImiah Visi 10 (1): $9-$ 20. https://doi.org/10.21009/JIV.1001.2.

Arifin, Sokhibul. 2016. "Perkembangan Kognitif Manusia Dalam Perspektif Psikologi Dan Islam." TADARUS 5 (1): 50-67-67. https://doi.org/10.29240/alquds.v1i1.183.

Chamidah, Atien Nur. 2009. "Deteksi Dini Gangguan Pertumbuhan dan Perkembangan Anak," Jurnal Pendidikan Khusus 4(3): 83-93. https://doi.org/10.21831/jpk.v4i3.789.

Hasbullah, Hasbullah. 2012. Dasar-Dasar Pendidikan. Jakarta: PT RajaGrafindo Persada.

Irma, C. N., Nisa, K., \& Sururiyah, S. K. (2019). Keterlibatan Orang Tua dalam Pendidikan Anak Usia Dini di TK Masyithoh 1 Purworejo. Jurnal Obsesi : Jurnal Pendidikan Anak Usia Dini, 3(1), 214. https://doi.org/10.31004/obsesi.v3i1.152

Jaipul L. Roopnarine, James E. Johnson. 2015. Pendidikan Anak Usia Dini Dalam Berbagai Pendekatan. Jakarta: Prenamedia Group.

Makhmudah, Siti. 2018. "Penguatan Peran Keluarga dalam Pendidikan Anak." Martabat: Jurnal Perempuan Dan Anak 2 (2): 269-286-286. https://doi.org/10.21274/martabat.2018.2.2.269-286.

Muhlis, Achmad. 2014. "Pengembangan Kurikulum Bahasa Arab Di Mtsn Sumber Bungur Pamekasan." OKARA: Jurnal Bahasa Dan Sastra 8 (1): 107-35. https://doi.org/10.19105/ojbs.v8i1.459. 
Mulyani, Novi. 2018. Perkembangan Dasar Anak Usia Dini. Yogyakarta: Gava Media.

Mu'min, Sitti Aisyah. 2013. "Teori Perkembangan Kognitif Jean Piaget." Al-TA'DIB 6 (1): 89-99. https://doi.org/10.31332/atdb.v6i1.292.

Nurkholida, Erna. 2018. "Developing Authentic Material Of Listening on Higher Education Based On Constructive Learning Of Jean Piaget and Vygotsky Theory." OKARA: Jurnal Bahasa Dan Sastra 12 (1): 59-74. https://doi.org/10.19105/ojbs.v12i1.1762.

Patilima, Hamid. 2015. Resiliensi Anak Usia Dini. Bandung: Alfabeta.

Paul, Suparno. 2001. Teori Perkembangan Kognitif Jean Piaget. Yogyakarta: Kanisius.

Permono, Hendarti. 2013. "Peran Orangtua Dalam Optimalisasi Tumbuh Kembang Anak Untuk Membangun Karakter Anak Usia Dini," June. http://publikasiilmiah.ums.ac.id/handle/11617/3994.

Pratiwi, Hardiyanti Ali, Ikta Yarliani, and Diyah Ageng. 2017. "Penyesuaian Konsep Matematika Dengan Perkembangan Kognitif Anak Usia Dini." Indonesian Journal of Islamic Early Childhood Education 2 (1): 51-64.

Santrock, John.W. 2010. Psikologi Pendidikan. Jakarta: Kencana Prenamedia Group.

Solihin, Rindu Dwi Malateki, Faisal Anwar, and Dadang Sukandar. 2013. "Kaitan Antara Status Gizi, Perkembangan Kognitif, dan Perkembangan Motorik Pada Anak Usia Prasekolah (Relationship Between Nutritional Status, Cognitive Development, and Motoric Development in Preschool Children)." Penelitian Gizi Dan Makanan (The Journal of Nutrition and Food Research) 36 (1): 62-72-72. https://doi.org/10.22435/pgm.v36i1.3396.62-72.

Sukaimi, Syafi'ah. 2012. "Peran Kedua Orang Tua dan Keluarga (Tinjuan Psikologi Perkembangan Islam Dalam Membentuk Kepribadian Anak)." Sosial Budaya 9 (1): 109-20. https://doi.org/10.24014/sb.v9i1.373.

Sukaimi, Syafi'ah. 2013. "Peran Orang Tua dalam Pembentukan Kepribadian Anak: Tinjauan Psikologi Perkembangan Islam." Marwah: Jurnal Perempuan, Agama Dan Jender 12 (1): 81-90. https://doi.org/10.24014/marwah.v12i1.515.

Suyadi. 2010. Psikologi Belajar PAUD. Yogyakarta: PT Pustaka Insan Madani.

Suyadi, Maulidya Ulfah. 2015. Konsep Dasar Paud. Bandung: PT Remaja Rosdakarya.

Ulfa, Khoiriyah. 2015. "Peran Keluarga Menurut Konsep Perkembangan Kepribadian Persfektif Psikologi Islam." Al-Adyan: Jurnal Studi Lintas Agama 10 (1): 123-40. https://doi.org/10.24042/ajsla.v10i1.1426. 